\title{
Arduino Based Design of Horizontal Wind Power Generator for Coastal Road Lighting
}

\author{
Sagita Rochman \\ Department of Electrical Engineering \\ University of PGRI Adi Buana Surabaya \\ sagita@unipasby.ac.id
}

\author{
Mochamad Taufiq Irvan Efendy \\ Department of Electrical Engineering \\ University of PGRI Adi Buana Surabaya \\ cipink.ii@gmail.com
}

\begin{abstract}
Increasing energy demand, depleting fossil fuel reserves, and environmental concerns have put renewable energy sources in the spotlight in Indonesia. Wind energy in particular, which has received a lot of attention because it is inexhaustible and friendly to the environment. The main problem of the two generating systems is not continuously available. Wind turbines are the main medium used to convert wind energy into electrical energy. A good wind turbine design will determine the performance of a wind power plant (PLTB). This tool is to control the electric power generated from the wind generator, the electric power generated from the generator will be measured the current and voltage. The way the tool works when the generator wheel rotates, the generator will produce electrical power which has been connected to the charger controller before the electric power is stored in the battery. The use of electric power from the battery will be converted using an inverter to convert the DC current to AC. This research was conducted on wind turbine generators in the use of coastal street lighting as objects to generate electric power in order to reduce the need for PLN electricity. This research was conducted on wind turbine generators in the use of coastal street lighting as objects to generate electric power in order to reduce the need for PLN electricity. The generator will generate electrical power which has been connected to the charger controller before the electric power is stored in the battery. The use of electric power from the battery will be converted using an inverter to convert the DC current to AC. This research was conducted on wind turbine generators in the use of coastal street lighting as objects to generate electric power in order to reduce the need for PLN electricity.
\end{abstract}

Keywords - Arduino, Control Charger, Generator, Inverter (key words)

\section{INTRODUCTION}

Increasing energy demand, depleting fossil fuel reserves, and environmental problems have put renewable energy sources in the spotlight of Indonesia. Wind energy, in particular, has become a major concern in the natural environment [5]. Wind is one of the natural resources that can be utilized to generate endless electrical energy, therefore wind energy is an alternative and environmentally friendly energy that can have good prospects to meet the shortage of electrical energy [2]. For example, in coastal areas, wind resources can be converted into electrical energy using wind turbines to be expected to be able to help people in the surrounding area [1].

The wind turbine is a device that can act as the main mover to generate electricity, that is, from the wind it is converted into electricity through components consisting of a rotor with blades, and electrical control system devices, towers, foundations [3]. Wind energy to generate electricity is very dependent on wind speed. In general, wind speeds in Indonesia, especially in East Java, range from 0 to $8 \mathrm{~m} / \mathrm{s}$. Wind speeds above $10 \mathrm{M}$ can be used as a source of electrical energy and then rectified and stored in an accumulator (battery) [4].

\section{METHODS}

\subsection{First Technical Planning Method}

For this research method is to make a block diagram. The function of the block diagram is as a reference in making a planned generator / turbine workflow for a process so that it can bring about changes in input and output in response to experiments that have been carried out systematically on these parts. In the experimental method that needs to be considered in carrying out experimental research, among others, is the introduction of the material used in the experiment, recording various things related to the research, 


\section{BEST}

which can be in the form of quantitative data about the performance of the research carried out, then proceed with carrying out the analysis. Figure 1 shows the research flow.

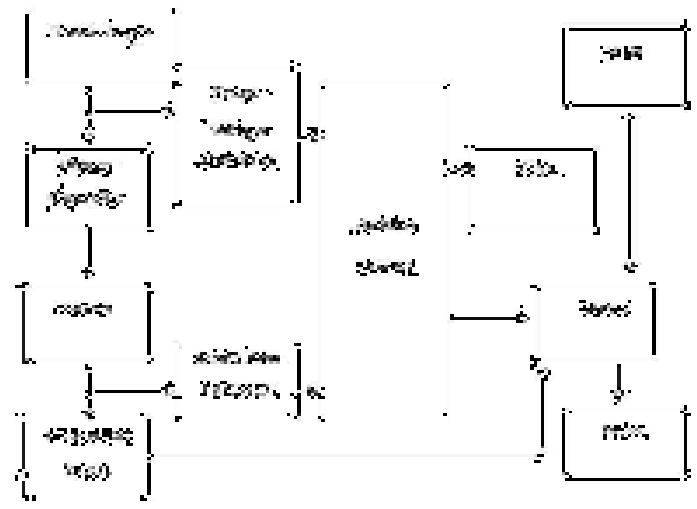

Fig. 1 Block Diagram

From the block diagram above, it can be seen about the description of the research object and the following is an explanation of the function of each of the blocks above

a. Wind turbines

Wind turbine with a horizontal shaft, shaped like an airplane propeller in general. In use, this wind turbine requires an adjustment to the wind direction to get wind speed.

b. Charger Control

An important component in Wind Power Generation. The charge controller functions for: Charging mode: Charging the battery (when the battery is charged, keeping it charging when the battery is full).

c. Inverters

Inverters are widely used in wind turbine applications which are generally used as AC supply. With an inverter, the DC voltage from the battery will be converted into an AC voltage that is ready to use.

d. Arduino Uno R3

Acting as a regulator and controller of the process for processing input and output data.

e. ACS 712 Current Sensor

Serves as a measure of the electric current of the inverter.

f. Voltage Sensor ZMPT101

Serves as a measure of the voltage from the inverter.

g. Relay

Serves to disconnect and connect the electric current from the generator and PLN.

h. LCD

Serves to display input data from each sensor.

i. LDR (Light Dependent Resistor)

Serves for the light sensor when the sensor is exposed to light, the light turns off

\subsection{Data Analysis Methods}

The analysis used is experimental analysis, to analyze the accuracy of the tool through the right components after the measurement test is carried out. Besides, descriptive analysis to describe the results of the experiment:

1. Take measurements of wind speed and map over a span of two days

2. Take measurements of the electrical energy generated by the generator within two days

3. Measure and compare the energy produced with the energy used for electric coastal road lighting

\subsection{Schematic Design}

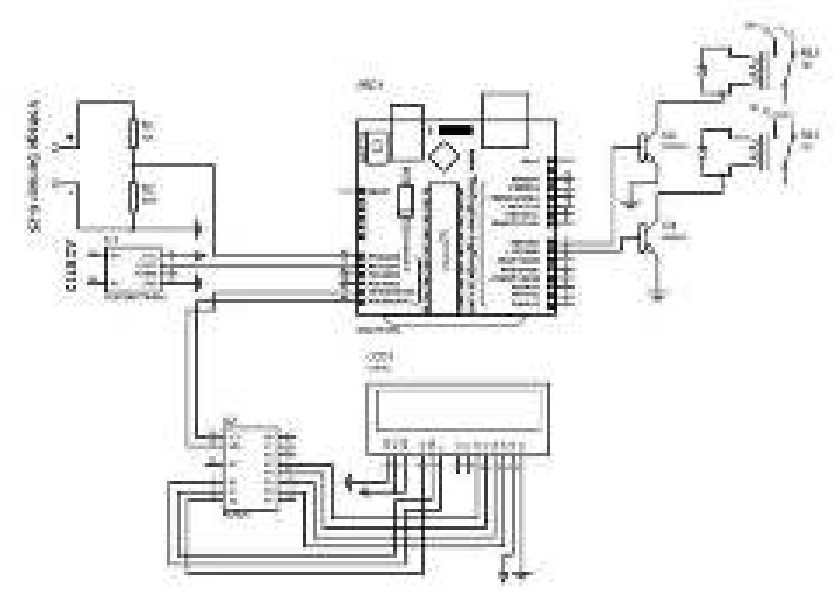

Fig. 2. Scematic Design

Schematicin figure 2 is a whole series of this tool consisting of Arduino Uno R3, ACS712 circuit, relay circuit, and voltage sensor circuit. with several other components, namely:

a. Arduino uno, as a system that controls the supporting components and as a communication with the application user interface.

b. Gear box, as a dynamo / generator drive

c. Motor generator, as a generator of dc current voltage

d. Relay, as a voltage breaker from PLN moved to the inverter.

e. LCD, as displaying the results in the form of voltage, amperage and watts

\section{RESULTS AND DISCUSSION}

\section{A. Test result}

This research has conducted experimental tools and observation tools so that researchers can analyze the experiment. Testing is carried out in several stages, including testing a series of tools 
and tool components and testing the application program that has been made. After further analysis,

\begin{tabular}{|c|c|c|}
\hline Hour & Wind Speed m/s & DC Voltage Output \\
\hline 08.00 & 1.5 & 0 \\
\hline 09.00 & 1.8 & 0 \\
\hline 10.00 & 1.9 & 0 \\
\hline 11.00 & 2.7 & 13.6 \\
\hline 12.00 & 2.5 & 13.2 \\
\hline 13.00 & 3 & 14.1 \\
\hline 14.00 & 3,4 & 14.5 \\
\hline 15.00 & 3,1 & 14.3 \\
\hline 16.00 & 2.9 & 13.9 \\
\hline $\begin{array}{c}\text { Averag } \\
\mathrm{e}\end{array}$ & 2,533333333 & 9,288888889 \\
\hline
\end{tabular}

a discussion of the performance and success of the horizontal axis wind generator that produces 20

\begin{tabular}{|c|c|c|}
\hline Hour & Wind Speed m / s & DC Voltage Output \\
\hline 08.00 & 1 & 0 \\
\hline 09.00 & 1.5 & 0 \\
\hline 10.00 & 1.3 & 0 \\
\hline 11.00 & 2.7 & 13.5 \\
\hline 12.00 & 3.5 & 14.7 \\
\hline 13.00 & 2,4 & 13.2 \\
\hline 14.00 & 1.9 & 11.7 \\
\hline 15.00 & 3,4 & 14.5 \\
\hline 16.00 & 3,2 & 14.2 \\
\hline Average & $\mathbf{2 , 3 2 2 2 2 2 2 2}$ & $\mathbf{9 , 0 8 8 8 8 8 8 9}$ \\
\hline
\end{tabular}

watts of Arduino-based power is conducted. In this study, the data were taken in five days starting at 08: 00-16: 00 WIB. Sample data were taken per 60 minutes for two days. And the average output voltage of the generator for all tests is shown in the table below.

Table 1 Measurement of Wind Speed and Voltage Output on Day 1

Table 2 Measurement of Wind Speed and Voltage Output on Day 2

From tables 1 and 2 the test of the wind speed results is to use an anemometer to be able to find out what the speed and Vout of the generator are. And the lowest average wind speed is $1 \mathrm{~m} / \mathrm{s}$ and is not able to produce an output voltage. On days 1 and 2 and the largest average wind speed is $2.3-2.5 \mathrm{~m} / \mathrm{s}$ during the day and can produce an output voltage of 9.2 volts DC

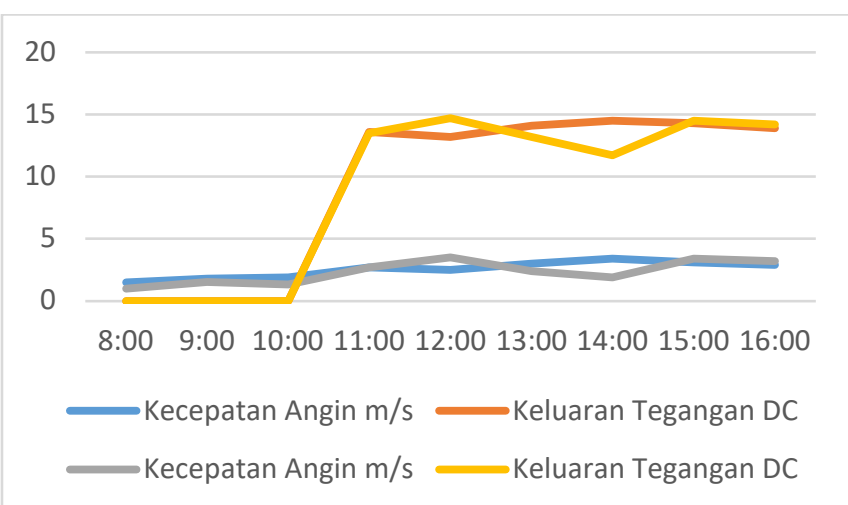

Fig. 3 Graph of Wind Speed and Voltage Output

Testing of the design results is carried out by checking the wind speed, namely by using an anemometer to find out how wind speed is and to produce the wind generator Vout voltage. In Figure 3 , it is shown that the wind speed and voltage output that can rotate the generator at least $2.5 \mathrm{~m} /$ $\mathrm{s}$ and 13.4 volts dc, the higher the wind speed, the greater the generator voltage output so that the power generated will also be greater. This happens because the high wind speed causes the greater the force that hits the surface of the windmill, as a result of this force the windmill rotates faster and continues to increase.

\section{B. Maximum Output Power Calculation Analysis}

Before calculating the maximum output power, in this study the capacity of the battery / battery used was 12 volts / 3.5 AH. So the ideal power inverter is:

Ideal power inverter $=$

$$
12 \mathrm{~V} \times 3.5 \mathrm{AH}=42 \text { watts }
$$

Assuming the battery / battery has a $20 \%$ deficiency, the maximum power of the inverter will $\mathrm{be}=(3.5-20 \%) \times 12$ volts. Inverter Power $=(3.5-$ $0.23) \times 12=2.75 \times 12=33$ Watts. So that the power efficiency of the inverter $=(42 / 33) \times 100 \%=80 \%$

\section{CONCLUSION}

Windmills are able to follow the direction of the wind so that the results obtained are quite maximum. The results of the measurement of wind speed for the location of placement in front of the house yard and obtained an average wind speed of $\pm 1.53 \mathrm{~m} / \mathrm{s}$ and not able to produce an output voltage. Whereas for the location of the placement 
of windmills in the coastal area the average wind speed obtained is $\pm 3.2 \mathrm{~m} / \mathrm{s}$ and can produce an output voltage of 225 volts AC. The generator will produce a minimum output voltage of $\pm 14 \mathrm{Vdc}$, wind speed of $3.1 \mathrm{~m} / \mathrm{s}$. The maximum power produced is 42 watts a watt with an inverter power efficiency of $80 \%$ or 33 watts.

\section{REFERENCES}

[1] Bahri, Syamsul Analysis of Wind Power Plants in Sungai Nibung Village, Teluk Pakedai District, Kubu Raya Regency. Tanjungpura. Tanjungpura University.

[2] Hoadi. 2018. Wind Power Generation in Indonesia.

[3] S. Soeripno M, Ibrahim, Malik, Analysis of Wind Energy Potential and Estimation of Wind Turbine Output Energy in Lebak, Banten.

[4] Latif, M. Nazir, R. Reza, H. 2013. Analysis of the Accumulator Charging Process on a Horizontal Axis Wind Turbine Prototype at Purus Beach, Padang. Padang. National Journal of Electrical Engineering Vol: 2 No. 1 ISSN; 2302-2949. Andalas University, Padang.

[5] Prasetiyo, B. Ramadhan, M, A, F. Rusdianto, M, D. 2017. Wind Power Mobile Phone Device. Semerang State Polytechnic.

[6] Sujiwa, Akbar, and Sagita Rochman. "Pengembangan Sistem Kontrol Serta Monitoring Suhu dan Volume Air Berbasis Web Pada Perangkat Desalinasi Air Laut." SNHRP (2019): 1-9.

[7] Mukhtar, M. Nushron Ali, and Sagita Rochman. "ANALISIS SIMULASI PROSES IRONING UNTUK MENGETAHUI KETINGGIAN DINDING BERDASARKAN VARIASI REDUKSI KETEBALAN DINDING." WAKTU: Jurnal Teknik UNIPA 15.2 (2017): 66-72.

[8] Rochman, Sagita, and M. Nushron Ali Mukhtar. "CLASSIFICATION OF THE QUALITY OF HONEY USING THE SPECTROFOTOMETER AND MACHINE LEARNING SYSTEM BASED ON SINGLE BOARD COMPUTER." Tibuana 2.01 (2019): 45-49.

[9] Rochman, Sagita. "DESIGN OF VERTICAL AXIS SAVONIUS WINDMILL FOR GENERATING ELECTRICITY USING PERMANENT MAGNET." Tibuana:: Journal of Applied Industrial Engineering 3.01 (2020): 61-66.

[10] Rochman, Sagita, and Akbar Sujiwa. "PENINGKATAN DAYA OUTPUT
GENERATOR LISTRIK TIPE AFPMG PADA PUTARAN RENDAH MENGGUNAKAN 3 ROTOR DAN 2 STATOR."

[11] Suryawati, Indri, and Sagita Rochman. "GENERATOR FUEL COST OPTIMIZATION USING ANT COLONY ALGORITHM." BEST: Journal of Applied Electrical, Science, \& Technology 1.1 (2019): 1-4. 